\title{
INVESTIGATION OF THE EFFECT OF DIOCTYLFLUORENYL-CO- BENZOTHIADIAZOLE BEARING POLYMER AND MWCNTS ON BIOSENSOR PERFORMANCE
}

\author{
Saniye Soylemez* \\ Department of Chemistry, Ordu University, Turkey, saniyesoylemez@odu.edu.tr \\ (iD) https://orcid.org/ 0000-0002-8955-133X)
}

Received: 11.12.2018, Accepted: 17.02.2019

Research Article

*Corresponding author

DOI: $10.22531 /$ muglajsci.495209

\begin{abstract}
The combination of conjugated polymers and carbon nanotubes serve great contributions in many research fields because of their superior characteristics. Herein, an electrochemical biosensor, using poly[(9,9-dioctylfluorenyl-2,7-diyl)-alt-co(1,4-benzo-\{2,1',3\}-thiadiazole)] (PFBTz) and multi-walled carbon nanotubes (MWCNTs) was constructed for glucose sensing. To create such a surface, a graphite electrode was coated with PFBTz and MWCNTs, respectively. Then, glucose oxidase (GOX) was immobilized onto this new platform using glutaraldehyde (GA) as the cross linker. The limit of detection, linear range and sensitivity values were found to be $0.018 \mathrm{mM}, 0.025-0.6 \mathrm{mM}$ and $66.0 \mu \mathrm{Am}^{-1} \mathrm{~cm}^{-2}$, respectively. The selectivity of the prepared biosensor was also examined in the presence of interferences and as a result, it has been observed that the biosensor response was much higher for glucose in all measurements. Surface characterizations before and after enzyme immobilization were done using scanning electron microscopy (SEM) and cyclic voltammetry (CV) techniques. In the final part of the study, the constructed biosensor was applied to beverages for glucose detection and very promising results were obtained. With this work, a robust, novel and economic sensing platform was prepared for glucose determination.
\end{abstract}

Keywords: Amperometric biosensor, conjugated polymer, carbon nanotube, glucose biosensor

\section{DIOKTILFLUORENIL-KO-BENZOTIYADIAZZL POLIMMER VE ÇOK DUVARLI KARBON NANOTÜPÜN BIYOSENSÖR PERFORMANSI ÜZERINE ETKISINIIN INCELENMESI}

\section{Özet}

Karbon nanotüp ve konjuge polimerlerin kombinasyonu çok iyi özelliklere sahip olmalarından dolayı birçok alanda güzel katkılar sağlamaktadır. Bu çalışmada, elektrokimyasal bir biyosensör 9,9-dioktilfluorenil-2,7-diyl) -alt-ko- (1,4-benzo- (2,1 ', 3\} -tiyadiazol) (PFBTz) ve çok duvarlı karbon nanotüplerin (MWCNTs) kullanılması ile glikoz tayini için kullanılmıştır. Böyle bir yüzey oluşturmak için, grafit elektrot yüzeyi sırasılyla PFBTz ve MWCNTs ile modifiye edilmiştir. Daha sonra glikoz oksidaz (GOx) bu yeni platform üzerine çapraz bağlayıcı olan gluteraldehit (GA) yardımıla immobilize edilmiştir. Tayin sınırı, lineer aralık ve hassasiyet değerleri sırasıyla $0.018 \mathrm{mM}, 0.025-0.6 \mathrm{mM}$ ve $66.0 \mu \mathrm{AmM}^{-1} \mathrm{~cm}^{-2}$ olarak bulunmuştur. Önerilen biyosensörün seçiciliği de, girișim yapan moleküllerin varlığında test edilmiştir ve biyosensör cevabının, tüm ölçümlerde glikoz için çok daha yüksek olduğu belirlenmiştir. Enzim immobilizasyonundan önce ve sonra yüzey karakterizasyonu, taramalı elektron mikroskobu (SEM) ve siklik voltametri (CV) teknikleri kullanılarak yapılmıştır. Çalışmanın son bölümünde ise, üretilen biyosensör kullanılarak içeceklerde glikoz tayini başarılı bir şekilde test edilmiştir. Bu çalışma ile glikozun tespiti için hızlı, yeni ve uygun maliyetli bir platform tasarlanmıştır.

Anahtar Kelimeler: Amperometrik biyosensör, iletken polimer, karbon nanotüp, glikoz biyosensörü

Cite

Soylemez, S., (2019). “Investigation of the effect of Dioctylfluorenyl-co-Benzothiadiazole bearing polymer and MWCNTs on biosensor performance”, Mugla Journal of Science and Technology, 5(1), 17-23.

\section{Introduction}

Development of new chemical sensing technologies has been growing continuously to control some important analyte levels such as glucose, cholesterol, urea etc. Electrochemical biosensing system serves a new trend in the diagnostic technology [1]. Excessive consumption of sugary drinks has been associated with high blood 
glucose levels and appears to be a major risk for many diseases, including cardiovascular diseases, obesity, heart problems and diabetes. In addition, since the characteristic of the food products can be affected by the amount of glucose, its detection in the food industry is very essential. Thus, fast, cheap and selective sensing of glucose level in food products continues to be of interest for both producers and consumers. Traditional analytical methods (spectrophotometric, chromatographic, etc.) used for such a purpose however, these techniques require qualified operators and longer analysis time to process and analyze the data [2]. Therefore, progress in electrochemical biosensing systems provides inexpensive and easy to use systems to detect various important analytes. Conjugated polymers (CPs) are of great importance in biosensor construction since they are regarded as useful anchor for localization of molecules. They have unique properties for creating easy, accurate and reasonable determination of analytes $[3,4]$. A number of articles on the conjugated polymer based sensors reported that the use of CPs was favored for the fabrication of a biosensing platform [5-8]. Multiwalled carbon nanotubes (MWCNTs) have been also extensively utilized in biosensor design since they possess unique features which make them particularly attractive for biosensing applications [9]. They can be used as immobilization platform and as electrochemical transducers, resulting in the enhancement of biosensor performance. Its properties of enlarging the electroactive surface area resulted in increased charge transfer and conductivity. A surface created together with the CPs serves great scaffolds for biomolecules via improving the biosensor performance. This made the combination very attractive as transducer-active materials.

With this motivation, herein a conjugated polymer poly((9,9-dioctylfluorenyl-2,7-diyl)-alt-co-(1,4-benzo-

$\left\{2,1^{\prime}, 3\right\}$-thiadiazole)) (PFBTz) and MWCNTs was used for the first time for electrochemical monitoring of glucose. To construct enzyme based biosensor, glucose oxidase (GOx), from Aspergillus niger, was used due to its high glucose selectivity, low cost and robust properties [10]. GOx catalyzes the oxidation of $\beta$-glucose to $\delta$ gluconolactone which is subsequently hydrolyzed into gluconic acid [11]. This redox enzyme converts glucose into gluconolactone under reduction of the FAD prosthetic group. During the enzymatic reactions, oxygen consumption can be determined at $-0.7 \mathrm{~V}$ (vs. Ag reference electrode) [12]. Proper attachment of the enzyme to transducer surface was achieved via gluteraldehyde cross linking agent. The together use of conjugated polymer and MWCTs brought higher and more stable biosensor responses and great biosensor characteristics compared to unmodified ones. The electrochemical measurements were done using amperometric detection technique at $-0.7 \mathrm{~V}$ versus $\mathrm{Ag}$ wire pseudo-reference electrode. The characterization studies were achieved for the designed biosensor and finally, the applicability of the biosensor was checked with real samples for glucose sensing successfully.
Scheme 1 depicts the surface modification of the proposed biosensor.

\section{Experimental}

\subsection{Chemicals and instrumentation}

Poly((9,9-dioctylfluorenyl-2,7-diyl)-alt-co-(1,4-benzo$\left\{2,1^{\prime}, 3\right\}$-thiadiazole)) (PFBTz) was purchased from American Dye Source, Inc (Quebec, Canada; www.adsdyes.com). Multi walled carbon nanotubes (MWCNTs), glutaraldehyde (GA) and chloroform were obtained from Sigma-Aldrich Co., LCC. (St. Louis, USA). Glucose oxidase (GOx, $\beta$-D-glucose: oxygen 1oxidoreductase, EC 1.1.3.4, 17300 units/g solid) from $A$. niger and $\beta$-D-glucose were purchased from Sigma. $\mathrm{Na}_{2} \mathrm{HPO}_{4}$ and $\mathrm{NaH}_{2} \mathrm{PO}_{4}$ (Fisher Scientific Company) were used for preparation of the $50 \mathrm{mM}$ phosphate buffer solutions during amperometric measurements and enzyme immobilization procedure.

EmStat3 potentiostat (PalmSens, Houten, The Netherlands) was used for all the amperometric measurements and cyclic voltammetry studies. As the working electrode, graphite electrodes $(3.05 \mathrm{~mm}$ diameter) were used. Ag wire and a Pt electrode were used as the pseudo-reference and counter electrodes, respectively. The results were reported as the average of three measurements and standard deviations were calculated as \pm SD. Modified surfaces were examined using Scanning electron microscope (SEM) (JEOL JSM6400 model.

\subsection{Biosensor preparation and amperometric detection}

Graphite rods were cleaned using an emery paper and washed with distilled water. PFBTz solution was prepared by dissolving $1.0 \mathrm{mg}$ PFBTz in $1.0 \mathrm{~mL}$ chloroform and $10 \mu \mathrm{L}$ aliquot of this solution were deposited on the cleaned graphite electrode surface. After drying process, $10 \mu \mathrm{L}$ aliquot of homogeneous suspension $0.25 \mathrm{mg}$ MWCNT were dispersed in $5 \mathrm{~mL}$ DMF by ultra-sonicating for 15 min to obtain a clear suspension) was cast on polymer modified electrode surface and the electrodes were left to dry at room temperature for $1.5 \mathrm{~h}$. For the enzyme immobilization, GOx solution was prepared in PBS (50 mM, pH 7.0) and drop cast on the modified electrode surface. After a while, the surface was covered with $5 \mu \mathrm{L} 1 \% \mathrm{GA}$ in order to stabilize the biomolecule on the polymer coated surface. Then, the electrode was allowed to wait for $2 \mathrm{~h}$ at room temperature and before amperometric measurements, the fabricated biosensor was rinsed with distilled water to get rid of impurities.

All the measurements were performed at room temperature $\left(25^{\circ} \mathrm{C}\right)$ in a reaction cell filled with PBS, $\mathrm{pH}$ 7.5 under mild stirring and constant potential $(-0.7 \mathrm{~V})$. After each measurement electrodes were cleaned with distilled water and buffer solution was refreshed. In amperometric measurements, the biosensor response is estimated recording the data before and after substrate 


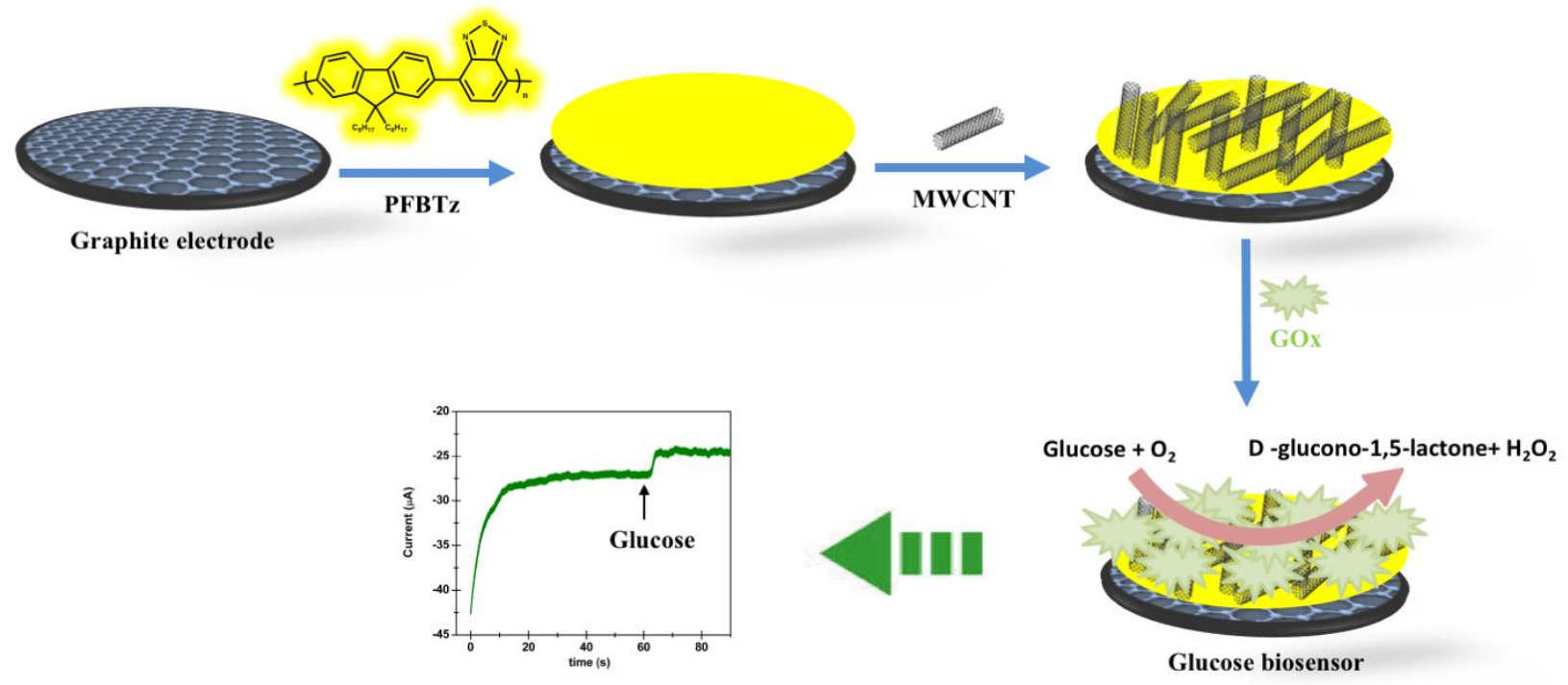

Scheme 1. Presentation of PFBTz/MWCNTs/GOx biosensor preparation.

injection in the reaction medium. Biosensor response was calculated by subtracting these two constant current values and reported as current $(\mu \mathrm{A})$.

\section{Results and discussion}

\subsection{Optimization studies}

The parameters, affecting the biosensor performance, were optimized by following four steps: Effect of the amount of conjugated polymer, MWCNTs, enzyme and $\mathrm{pH}$. The use of conjugated polymer modified surfaces led to an excellent immobilization platform, which provides effective binding of the enzyme on conjugated polymer surface. Without the contribution of conjugated polymer, it is hard to get stable and consecutive signals for glucose sensing since CPs have resulted in fundamental insights into biosensor construction because of their interesting properties. Firstly, to find optimum polymer amount, a range of PFBTz from 0.5 to $1.5 \mathrm{mg}$ was dissolved in chloroform and $10 \mu \mathrm{L}$ aliquots of these solutions were deposited on cleaned electrodes. During this experiment, all other parameters were under constant conditions and the highest performance was found with $1.0 \mathrm{mg}$ PFBTz (Figure 1A).

Secondly, MWCNT amount was investigated and different electrodes were constructed with varying nanotube amounts between 0.05 and $0.5 \mathrm{mg}$. According to the results, maximum interaction and satisfactory biomolecule deposition were achieved with $0.25 \mathrm{mg}$ MWCNTs. (Figure 1B). Due to diffusional restrictions on biosensor response, when electrodes were prepared higher than the optimum amount biosensor responses were decreased. On the other hand, with lower MWCNT amounts biomolecule may not be fixed properly onto the surface of the transducer. For the third optimization step, five electrodes were prepared with the different amounts of GOx (0.5-1.5 mg with the 0.25 increments) and then, their biosensor responses were recorded. Maximum performance was observed for $1 \mathrm{mg} \mathrm{GOx}$ and then, used for further experiments (Figure 1C). Without this amount, enzyme molecules may not be localized properly on the electrode surface that resulted in leaching of biomolecules from the surface. As the final step, optimum $\mathrm{pH}$ value was analyzed. Since it is known that the GOx is an active enzyme in the range of pH 3.0 and pH 8.0 [13] different $50 \mathrm{mM}$ buffer solutions having $\mathrm{pH}$ values as 6.0 8.0 were prepared. The best sensor performance was obtained with pH 7.5 (Figure 1D).
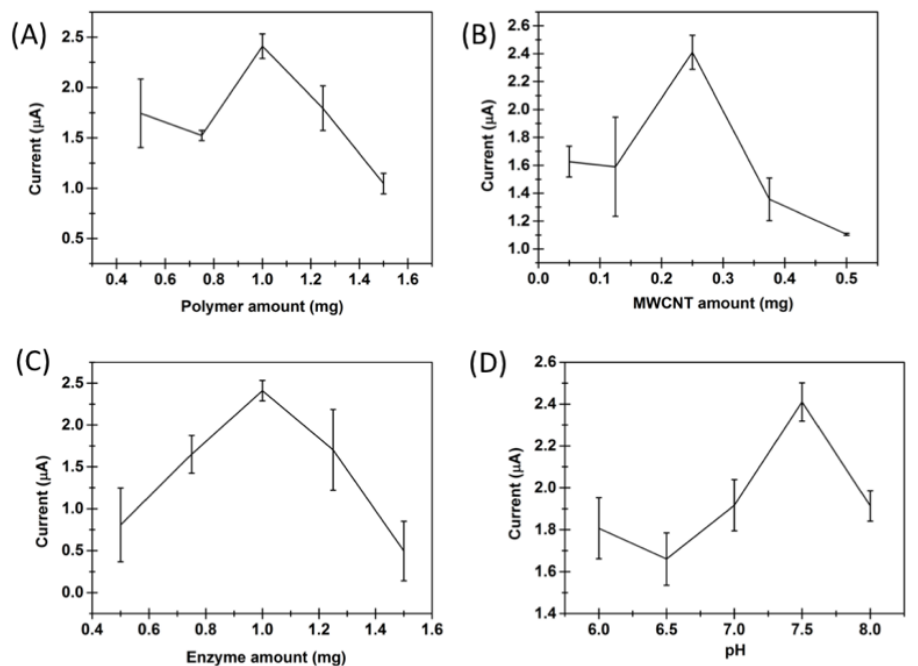

Figure 1. Influence of the amperometric signal of the biosensor on amount of (A) PFBTz polymer, (B) MWCNTs, (C) enzyme and (D) pH on biosensor response. 


\subsection{Surface characterizations}

In order to investigate the electroactive surface area before and after modifications, CV responses were performed covering a potential range from -0.4 to $0.8 \mathrm{~V}$ with the scan rate of $100.0 \mathrm{mV} \mathrm{s}^{-1}$ (in $5.0 \mathrm{mM} \mathrm{Fe}(\mathrm{CN}) 6^{3-/ 4-}$ solution containing $0.1 \mathrm{M} \mathrm{KCl}$ and $50.0 \mathrm{mM}$ PBS) (Figure 2). The three electrode system was constructed and used the same reference and counter electrodes just like in amperometric measurements. The average values were estimated using the Randles-Sevcik equation [14] and reported as $0.12 \mathrm{~cm}^{2}$ for the bare graphite electrode, $0.204 \mathrm{~cm}^{2}$ for the graphite/PFBTz/MWCNTs and the $0.113 \mathrm{~cm}^{2}$ for the graphite/PFBTz/MWCNTs /GOx.

As shown in Figure 2, when the PFBTz and MWCNTs modifications were done both electron transfer rate and the electroactive surface area increased. After enzyme deposition, the peak current was decreased because of the insulating character of the biological molecules, however the surface was sufficient enough for an effective electron transfer.

Surface modifications of the biosensor were investigated using scanning electron microscopy (SEM) technique. Figure 3 shows SEM images of pristine PFBTz, PFBTz/MWCNTs and PFBTz/MWCNTs/GOx modified electrode surfaces, respectively. When PFBTz coated surface (Figure 3A) was covered with MWCNTs, the modifications in the morphology of a polymer matrix combined with the MWCNTs were seen clearly in Figure 3B. In this figure, the typical fibrous shape of MWCNTs was seen. It is obviously seen that the immobilization of the enzyme molecules brings the different surface morphology (Figure 3C).

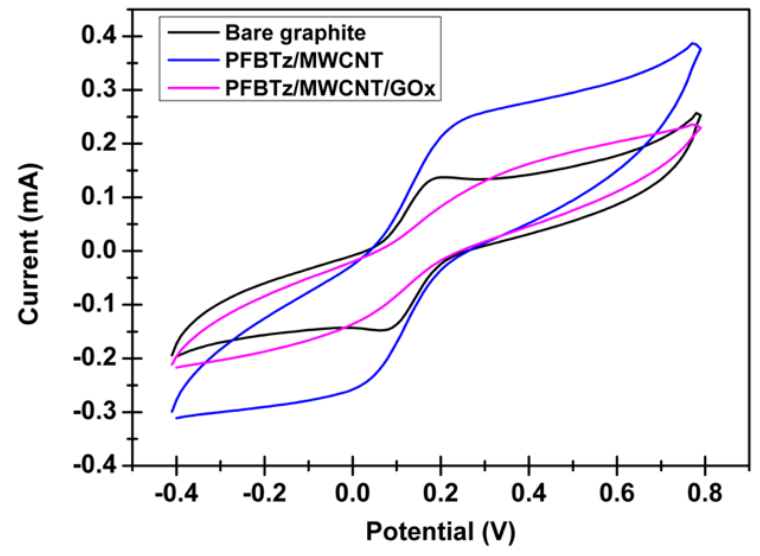

Figure 2. Cyclic voltammograms results for a bare graphite, PFBTz/MWCNTs and PFBTz/MWCNTs/GOx in $5.0 \mathrm{mM} \mathrm{Fe}(\mathrm{CN})_{6}^{3-/ 4-}$ containing $0.1 \mathrm{M} \mathrm{KCl}$.
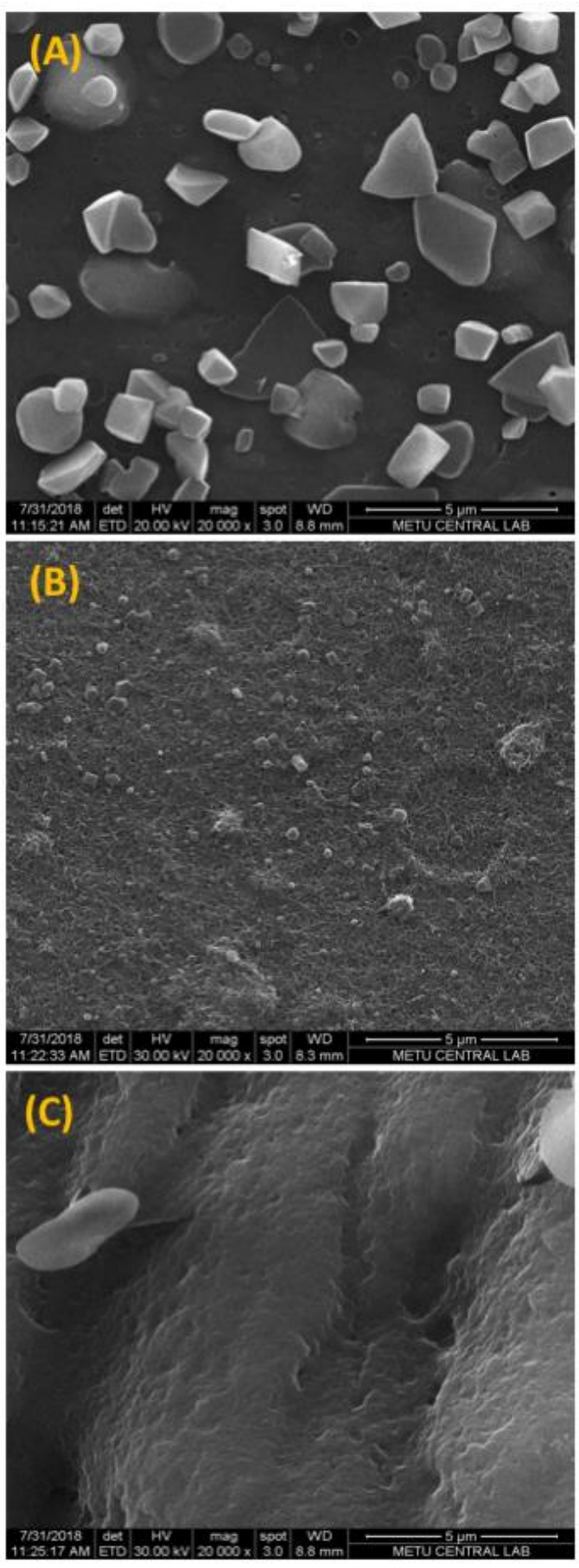

Figure 3. SEM micrographs of (A) pristine PFBTz; (B) PFBTz/MWCNTs and (C) PFBTz/MWCNTs/GOx under the optimized conditions. 


\subsection{Analytical properties and sample analysis}

Under the optimized conditions, the calibration curve of the PFBTz/MWCNT/GOx biosensor for glucose is given in Figure 4. Linearity ranges of the proposed biosensor was determined as 0.025-0.6 $\mathrm{mM}$ with the equation of $\mathrm{y}$ $=4.1064 \mathrm{x}+0.231\left(\mathrm{R}^{2}=0.992\right)$. Michaelis-Menten constant $K_{M}^{a p p}$ and $I_{\max }$ values were estimated from Lineweaver-Burk plot (1/I vs $1 /[\mathrm{S}]$ ) and found to be 0.22 $\mathrm{mM}$ and $I_{\max }=2.5 \mu \mathrm{A}$, respectively. In this work, it was aimed to produce probes with superior properties compared to the ones reported in literature (Table 1). A glucose biosensor was developed by Liu et al and $K M^{A p p}$ value was reported as $8.2 \mathrm{mM}$ [15]. In another work, SNS$\mathrm{NH}_{2} / \mathrm{SNS}-\mathrm{NH}_{2} \mathrm{Fc}$ :4-(2,5-di(thiophen-2-yl)-1 $H$-pyrrol-1yl)amidoferrocenyldithiophosphonate-co-4-(2,5-

di(thiophen-2-yl)-1H-pyrrol-1 yl) aniline was used as an immobilization matrix and $K_{M}^{a p p}$ value found as $3.86 \mathrm{mM}$ [16]. Compared to values reported in the literature 0.97 $\mathrm{mM}$ for polyaniline-g-poly(ethylene glycol)/GOx, [6] $2.2 \mathrm{mM}$ for GOx/MWCNTs/CS/GCE [17] and 4.73 for Graphene-AuNPs-GOD [18] were obtained with the proposed biosensor. Moreover, analytical results of PFBTz/MWCNTs/GOx was compared in Table 1 with other electrochemical biosensor reported recently. The limit of detection (LOD) was estimated as $0.018 \mathrm{mM}$ according to the signal-to noise ratio $\mathrm{S} / \mathrm{N}=3$ criterion. Sensitivity value was also determined to be $66.0 \mu \mathrm{AmM}^{-}$ ${ }^{1} \mathrm{~cm}^{-2}$. Since carbon nanotubes and $\mathrm{CPs}$ are both fascinating for their unique electrochemical immobilization matrix for the enzyme herein, the results show that the polymer and carbon nanotube combination resulted in good biosensor performance. For a detailed analytical characterization of the proposed biosensor (PFBTz/MWCNTs/GOx), a device in the absence of both polymer and MWCNTs was also constructed and their current responses were compared. As shown in Figure 4, the PFBTz/MWCNTs/GOx gives a higher response toward glucose than the PFBTz/GOx and MWCNTs/GOx modified ones. Through the use of PFBTz layer together with MWCNTs, the sensing response of the biosensor was increased by as much as two folds.

Since several ingredients such as electrochemically interfering molecules found in the sample matrix can affect the accuracy of the glucose detection, herein potential interferents such as citric acid and urea were studied on the amperometric response of $0.5 \mathrm{mM}$ glucose. As shown in Figure 5, after glucose addition in the medium, the change of current was detected clearly. On the contrary, the sensor did not give a significant signal to related interferents. These results revealed the PFBTz/MWCNTs/GOx biosensor shows good selectivity for glucose. These species were directly added to the cell instead of glucose and their responses were recorded at constant potential. Moreover, the selectivity of the biosensor was tested in the presence of different sugars (galactose, mannose, fructose, sucrose and xylose) and results were shown in Figure 6. The results reveal that the designed sensor shows great selectivity in the existence of sugars.

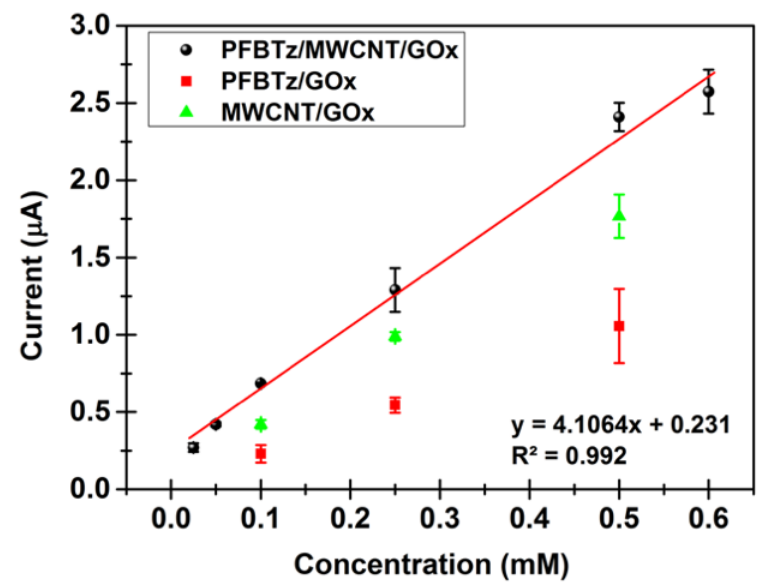

Figure 4. Current response vs concentration for the PFBTz/MWCNT/GOx enzyme electrode (in $50 \mathrm{mM}$ phosphate buffer, $\mathrm{pH} 7.5,25^{\circ} \mathrm{C}$ ).

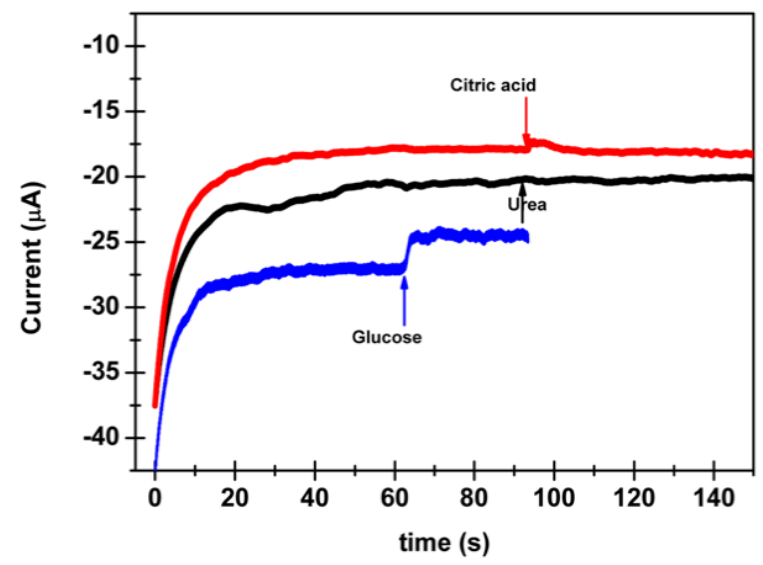

Figure 5. Amperometric responses of PFBTz /MWCNT/GOx biosensor to glucose and interfering species with citric acid and urea (in $50 \mathrm{mM}$ phosphate buffer, $\mathrm{pH} 7.5,25^{\circ} \mathrm{C}$ ).

Proposed glucose biosensor was tested on commercial beverages. Samples were added into the reaction medium with no pretreatment instead of substrate solution. Glucose content in beverages was measured by glucose biosensor. Glucose content of beverages was determined using the equation of the calibration curve. As shown in Table 2, consistency of the results provide that the fabricated biosensor is appropriate for monitoring the concentration of the glucose with reliable accuracy. 
Table 1. Comparison of analytical parameters of glucose biosensors in the literature (NR: Not reported).

\begin{tabular}{lcccc}
\hline Matrices on electrodes & $\begin{array}{c}\text { LOD } \\
(\mathrm{mM})\end{array}$ & $\begin{array}{c}\text { Sensitivity } \\
\left(\mu \mathrm{AmM}^{-1} \mathrm{~cm}^{-2}\right)\end{array}$ & $\begin{array}{c}\mathrm{K}_{\mathrm{M}}^{\mathrm{app}} \\
(\mathrm{mM})\end{array}$ & Reference \\
\hline PFBTz/MWCNTs/GOx & 0.018 & 66.0 & 0.22 & This work \\
GOx/Naf/MnO2-GNR/SPCE & 0.050 & 56.32 & $\mathrm{NR}$ & {$[19]$} \\
MWCNT/GO/GOx & 0.028 & 3.37 & $\mathrm{NR}$ & {$[20]$} \\
GOx/MWCNTs/CS/GCE & 0.01 & 13 & 2.2 & {$[17]$} \\
PPy/PAN-MWCNT/SPCE & 0.015 & 5.41 & $\mathrm{NR}$ & {$[21]$} \\
\hline
\end{tabular}

\section{Conclusion}

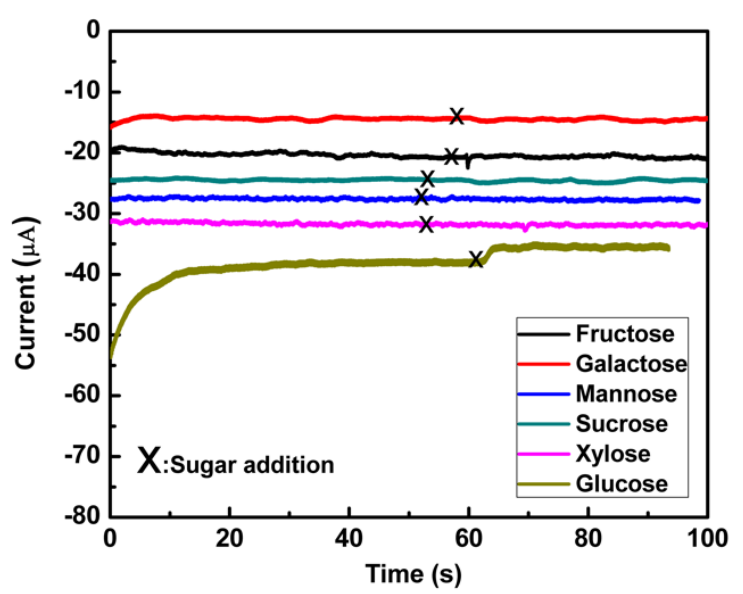

Figure 6. Selectivity of the PFBTz/MWCNT/GOx biosensor toward the different sugars.

Table 2. Comparison of the biosensor for glucose analyses in beverages.

\begin{tabular}{lccc}
\hline Sample & \multicolumn{2}{c}{ Glucose Content (mM) } & \\
& $\begin{array}{c}\text { Theoretical } \\
\text { Value }\end{array}$ & $\begin{array}{c}\text { PFBTz/ } \\
\text { MWCNTs/GOx }\end{array}$ & $\begin{array}{c}\text { Relative } \\
\text { Error } \\
(\%)\end{array}$ \\
\hline $\mathrm{S}^{\circledR}$ Milk & 0.255 & 0.24 & -5.88 \\
$\mathrm{~L}^{\circledR}$ Lemon & 0.25 & 0.249 & -0.4 \\
\hline
\end{tabular}

In this work, glucose biosensor was fabricated based on enzyme immobilized PFBTz/MWCNTs surface. As well as optimization and characterization studies, the system has been used to monitor glucose content in the beverages. Herein, for the first time, a constitution a surface using poly((9,9-dioctylfluorenyl-2,7-diyl)-alt-co(1,4-benzo- $\{2,1,3\}$-thiadiazole)) (PFBTz) and multiwalled carbon nanotubes (MWCNTs) was used for glucose sensing. In order to investigate the surface morphology and evaluate the electrochemical properties of the biosensor, SEM and CV techniques were used. The constructed enzyme electrodes have good $K_{M} a p p$, high sensitivity and very low LOD values. The remarkable findings indicated that the results of sensing were coherent and reproducible means that the proposed biosensor can be a good tool for glucose sensing.

\section{Acknowledgment}

S. Soylemez especially thanks to Prof. Dr. Levent Toppare for his support in this study.

\section{References}

[1]Harper, A. and Anderson, M.R. "Electrochemical glucose sensors - developments using electrostatic assembly and carbon nanotubes for biosensor construction", Sensors, 10, 8248-8274, 2010.

[2]Wang, J. "Electrochemical Glucose Biosensors", Chem. Rev., 108, 814-825, 2008.

[3]Singh, S., Chaubey, A., Malhotra, B.D. "Amperometric cholesterol biosensor based on immobilized cholesterol esterase and cholesterol oxidase on conducting polypyrrole films", Anal. Chim. Acta, 502, 229-234, 2004.

[4]Cesarino, I., Moraes, F.C., Lanza, M.R.V., Machado, S.A. "Electrochemical detection of carbamate pesticides in fruit and vegetables with a biosensor based on acetylcholinesterase immobilised on a composite of polyaniline-carbon nanotubes", Food Chem., 135, 873$879,2012$.

[5]Soylemez, S., Yilmaz, T., Buber, E., Udum, Y.A., Ozcubukcu, S., Toppare, L. "Polymerization and biosensor application of water soluble peptide-SNS type monomer conjugates", J.Mat.Chem. B., 5, 7384-7392, 2017.

[6]Bicak, T.C., Gicevičius, M., Gokoglan, T.C., Yilmaz, G., Ramanavicius, A., Toppare, L., Yagci, Y. "Simultaneous and sequential synthesis of Polyaniline-g-poly(ethylene 
glycol) by combination of oxidative polymerization and CuAAC click chemistry: A water-soluble", Macromolecules, 50, 1824-1831, 2017.

[7]Malhotra, B. D. and Chaubey, A. "Biosensors for clinical diagnostics industry", Sensor. Actuat. B-Chem., 91, 117127,2003

[8]Mazeiko, V., Kausaite-Minkstimiene, A., Ramanaviciene, A., Balevicius, Z., Ramanavicius, A. "Gold nanoparticle and conducting polymer-polyanilinebased nanocomposites for glucose biosensor design", Sens. Actuat. B-Chem., 189, 187-193, 2013.

[9]Siriviriyanun, A., Imae, T., Nagatani, N. "Electrochemical biosensors for biocontaminant detection consisting of carbon nanotubes, platinum nanoparticles, dendrimers, and enzymes", Anal. Biochem., 443, 169-171, 2013.

[10]Yoo, E. and Lee, S. "Glucose biosensors: an overview of use in clinical practice", Sensors, 10, 4558-4576, 2010.

[11]Bankar, S.B., Bule, M.V., Singhal, R.S., Ananthanarayan, L. "Glucose oxidase - An overview", Biotechnol. Adv., 27, 489-501, 2009.

[12]Leskovac V., Trivić, S., Wohlfahrt, G., Kandrac, J., Pericin, D. "Glucose oxidase from Aspergillus niger: the mechanism of action with molecular oxygen, quinones, and one-electron acceptors", Int. J. Biochem. Cell Biol., 37, 731-750, 2005

[13]Brights, H.J. and Appleby, M. "The pH Dependence of the Individual Steps in the Glucose Oxidase Reaction", $J$. Biol. Chem., 244, 3625-3634, 1969.

[14]Bard, A.J., and Faulkner, L.R. "Electrochemical methods: Fundamentals and applications", New York: John Wiley, 2000.

[15]Liu, Y., Wang, M., Zhao, F., Xu, Z., Dong, S. "The direct electron transfer of glucose oxidase and glucose biosensor based on carbon nanotubes/chitosan matrix", Biosens. Bioelectron. 21, 984-988, 2005.

[16]Ayranci, R., Demirkol, D.O., Ak, M., Timur, S. "Ferrocene-functionalized 4-(2,5-Di(thiophen-2-yl)-1Hpyrrol-1-yl)aniline: A novel design in conducting polymer-based electrochemical biosensors", Sensors, 15, 1389-1403, 2015.

[17]Deng, S., Jian, G., Lei, J., Hu, Z., Ju, H. "A glucose biosensor based on direct electrochemistry of glucose oxidase immobilized on nitrogen-doped carbon nanotubes", Biosens. Bioelectron., 25, 373-377, 2009.

[18]Chen, Y., Li, Y., Sun, D., Tian, D., Zhang, J., Zhu, J.J. "Fabrication of gold nanoparticles on bilayer graphene for glucose electrochemical biosensing", J. Mater. Chem., 21, 7604-7611, 2011.

[19]Vukojević, V., Djurdjić, S., Ognjanović, M., Fabián, M., Samphao, A., Kalcher, K., Stanković, D.M. "Enzymatic glucose biosensor based on manganese dioxide nanoparticles decorated on graphene nanoribbons", $J$. Electroanal. Chem. 823, 610-616, 2018.

[20]Palanisamy, S., Cheemalapati, S., Chen, S.M. "Amperometric glucose biosensor based on glucose oxidase dispersed in multiwalled carbon nanotubes/graphene oxide hybrid biocomposite", Mater. Sci. Eng. C, 34, 207-213, 2014.
[21]Ekabutr, P., Chailapakul, O., Supaphol, P. "Modification of Disposable Screen-Printed Carbon Electrode Surfaces with Conductive Electrospun Nanofibers for Biosensor Applications", J. Appl. Polym. Sci., 130, 3885-3893, 2013. 